\title{
Drive for patent-free innovation gathers pace
}

Declan Butler, Paris

A group of top scientists and economists are asking the World Intellectual Property Organization (WIPO) in Geneva to promote 'open' models of innovation that don't rely on patents.

The group believes that innovation based on freely available knowledge can be effective not just in areas where it has established a foothold - such as genome sequence data - but also in sectors where patent protection is entirely dominant, such as drug development (see Nature 424, 10-11;2003).

In a 7 July letter to Kamil Idris, directorgeneral of the WIPO, 59 scientists and economists call attention to the "explosion of open and collaborative projects to create public goods" in recent years, including the Human Genome Project, the open-source software movement, and Internet standards. Such projects show that "one can achieve a high level of innovation in some areas of the modern economy without intellectual property protection", says the letter, arguing that

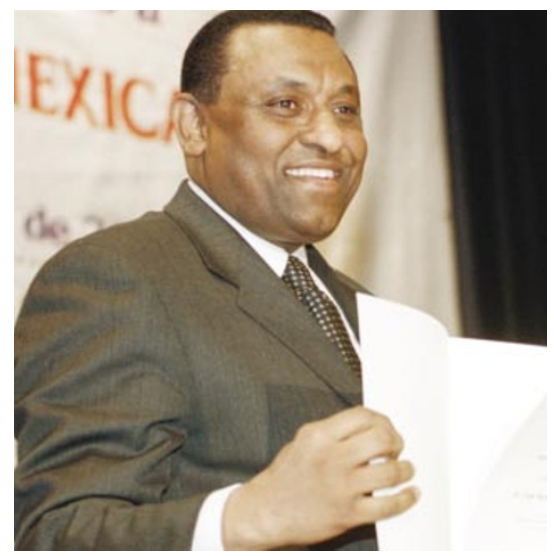

Kamil Idris is being asked to assess the merits of an open approach to intellectual property.

"excessive, unbalanced or poorly designed intellectual property protections may be counterproductive". It calls on the WIPO to hold a major conference on these models during 2004.

\section{Malaysia puts biovalley under wraps}

\section{David Cyranoski, Kuala Lumpur}

The Malaysian government is quietly launching a major project to harness the country's abundant natural biodiversity to create a viable biotechnology industry.

Over the next three years, it plans to invest 600 million ringgits (US\$160 million) to build three research institutes, dedicated to molecular biology, plant biotechnology and drug development. Based at an 80 hectare campus in Dengkil, 45 kilometres south of Kuala Lumpur, the institutes are scheduled to open in 2006.

But in contrast to similar initiatives elsewhere, BioValley Malaysia is being set up in an atmosphere that borders on secrecy. Although Malaysian biologists welcome the initiative, most won't discuss it on the record.

Even government officials don't want to talk about the project, which was announced

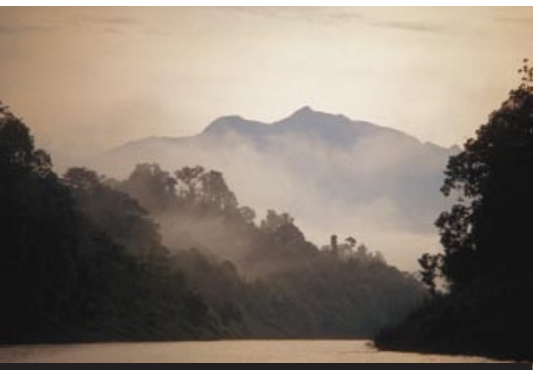

Malaysia hopes to build a biotech industry on the back of its rainforest biodiversity. by Prime Minister Mahathir bin Mohamad in May. "We want to get the project off the ground rather than talk about it," says an official at the science ministry.

A university researcher, who didn't want to be named, says that Mahathir wants to keep the project low profile, after a comparable information-technology initiative in 1997 failed to meet its advertised goals. The government is also sensitive to charges that it is allowing private investors to exploit Malaysia's rich biodiversity.

This biodiversity distinguishes the project from other biotechnology parks, says the ministry spokesperson. Three companies have already agreed to locate themselves in the park and the government is negotiating with another 20.

Researchers are already tapping into the country's biodiversity. A collaboration between several Malaysian institutes and the Massachusetts Institute of Technology, for example, is looking at the plant tongkat ali - used in Malaysia to treat impotency.

The government hopes that the biovalley will enable firms to develop drugs locally by bioprospecting in Malaysia. But some analysts doubt whether Malaysian investors are ready to back long-term, research-intensive ventures, such as biotech companies. And researchers say that bureaucratic restrictions on their mobility, and on the efficient filing of patents, will make it difficult for a biotechnology sector to take root.
The signatories include Joseph Stiglitz of Columbia University in New York, who received the 2001 Nobel prize for economics; John Sulston of the Wellcome Trust Sanger Institute near Cambridge, UK, winner of the 2002 Nobel prize for medicine; James Orbinski, former president of Médecins Sans Frontières; and Richard Stallman, a computer scientist regarded by many as the 'father' of the open-source software movement.

Francis Gurry, an assistant director-general at the WIPO, said that the organization welcomed the idea. "The use of open and collaborative development models for research and innovation is a very important and interesting development," he said in a statement. "The director-general looks forward with enthusiasm to taking up the invitation to organize a conference to explore the scope and application of these models."

Advocates of open-source innovation want the WIPO and other public agencies to rethink how innovation works, says James Love, director of the Washington-based Consumer Project on Technology and a signatory to the letter. Open research for drug development is one of the initiative's main targets, he says. Some of the authors are also pursuing the idea of an international treaty to encourage governments to fund drug research and put the results directly into the public domain.

Love argues that research results should ultimately become a freely available commodity, with drug companies competing to market generics of any drugs developed. The current system, in which drug research and development is carried out by drug companies that keep patent rights for up to 20 years, is grossly inefficient and results in excessive prices so that those who need the drugs most cannot afford them, argues Love.

Yet to be fleshed out are details of how such a model would work, and how competitive forces could be maintained within it. But in May, the general assembly of the World Health Organization instructed agency officials to draft terms of reference during 2004 for a new evaluation of intellectual property, innovation and public health. Consideration of open-science models is expected to be part of this exercise.

"The success of the Internet and of open-source software has driven home just how far open and collaborative projects can go," says Hal Varian, an economist at the University of California, Berkeley, who has also signed the 7 July letter.

Another signatory, Paul David, an economist at Stanford University, argues that systems such as free and open-source software are not at odds with intellectual property rights protection, but rather a choice by creators and society as to the benefits they want to obtain. 